\title{
Effect of regional precursor emission controls on long-range ozone transport - Part 2: Steady-state changes in ozone air quality and impacts on human mortality
}

\author{
J. J. West ${ }^{1}$, V. Naik ${ }^{2,}$, L. W. Horowitz ${ }^{3}$, and A. M. Fiore ${ }^{3}$ \\ ${ }^{1}$ University of North Carolina, Chapel Hill, NC, USA \\ ${ }^{2}$ Princeton University, Princeton, NJ, USA \\ ${ }^{3}$ NOAA Geophysical Fluid Dynamics Laboratory, Princeton, NJ, USA \\ *now at: ATMOS Research and Consulting, Lubbock, TX, USA
}

Received: 16 February 2009 - Published in Atmos. Chem. Phys. Discuss.: 16 March 2009

Revised: 11 July 2009 - Accepted: 17 July 2009 - Published: 21 August 2009

\begin{abstract}
Large-scale changes in ozone precursor emissions affect ozone directly in the short term, and also affect methane, which in turn causes long-term changes in ozone that affect surface ozone air quality. Here we assess the effects of changes in ozone precursor emissions on the longterm change in surface ozone via methane, as a function of the emission region, by modeling $10 \%$ reductions in anthropogenic nitrogen oxide $\left(\mathrm{NO}_{\mathrm{x}}\right)$ emissions from each of nine world regions. Reductions in $\mathrm{NO}_{\mathrm{x}}$ emissions from all world regions increase methane and long-term surface ozone. While this long-term increase is small compared to the intraregional short-term ozone decrease, it is comparable to or larger than the short-term inter-continental ozone decrease for some source-receptor pairs. The increase in methane and long-term surface ozone per ton of $\mathrm{NO}_{\mathrm{x}}$ reduced is greatest in tropical and Southern Hemisphere regions, exceeding that from temperate Northern Hemisphere regions by roughly a factor of ten. We also assess changes in premature ozonerelated human mortality associated with regional precursor reductions and long-range transport, showing that for $10 \%$ regional $\mathrm{NO}_{\mathrm{x}}$ reductions, the strongest inter-regional influence is for emissions from Europe affecting mortalities in Africa. Reductions of $\mathrm{NO}_{\mathrm{x}}$ in North America, Europe, the Former Soviet Union, and Australia are shown to reduce more mortalities outside of the source regions than within. Among world regions, $\mathrm{NO}_{\mathrm{x}}$ reductions in India cause the greatest number of avoided mortalities per ton, mainly in India itself. Finally, by increasing global methane, $\mathrm{NO}_{\mathrm{x}}$ reductions in one hemisphere tend to cause long-term increases in ozone concentration and mortalities in the opposite hemi-
\end{abstract}

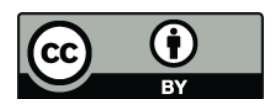

Correspondence to: J. J. West (jasonwest@unc.edu) sphere. Reducing emissions of methane, and to a lesser extent carbon monoxide and non-methane volatile organic compounds, alongside $\mathrm{NO}_{\mathrm{x}}$ reductions would avoid this disbenefit.

\section{Introduction}

Tropospheric ozone has been observed to have increased in polluted regions since preindustrial times, while the global ozone background has also increased (Vingarzan, 2004). Increases in ozone in polluted regions have been attributed mainly to increases in anthropogenic emissions of nitrogen oxides $\left(\mathrm{NO}_{\mathrm{x}}\right)$, non-methane volatile organic compounds (NMVOCs), and carbon monoxide (CO), while the global background increase has been attributed mainly to anthropogenic $\mathrm{NO}_{\mathrm{x}}$ and methane $\left(\mathrm{CH}_{4}\right)$ (Wang and Jacob, 1998; Lelieveld and Dentener, 2000). Since $\mathrm{NO}_{\mathrm{x}}$, NMVOCs, and $\mathrm{CO}$ react rapidly to form ozone - on the scales of hours to weeks after emissions - the effects of changes in emissions of these precursors on ozone are realized quickly, within a year after the change in emissions. Among the ozone precursors, $\mathrm{CH}_{4}$ has a significantly longer lifetime - a perturbation lifetime of about 12 years (Forster et al., 2007) - causing ozone concentrations to respond more gradually to sustained changes in $\mathrm{CH}_{4}$ emissions.

Global reductions in $\mathrm{NO}_{\mathrm{x}}$ emissions have been shown previously to cause concentrations of the hydroxyl radical $(\mathrm{OH})$ to decrease (Wang and Jacob, 1998; Fuglestvedt et al., 1999; Wild and Prather, 2000; Wild et al., 2001; Fiore et al., 2002). Since $\mathrm{OH}$ is the major sink for $\mathrm{CH}_{4}, \mathrm{NO}_{\mathrm{x}}$ reductions cause $\mathrm{CH}_{4}$ concentrations to increase. For global climate forcing, the increase in $\mathrm{CH}_{4}$ outweighs the decrease in ozone, causing

Published by Copernicus Publications on behalf of the European Geosciences Union. 
a net positive radiative forcing from global $\mathrm{NO}_{\mathrm{x}}$ emission reductions (Fuglestvedt et al., 1999; Wild et al., 2001) and surface $\mathrm{NO}_{\mathrm{x}}$ reductions in all world regions (Naik et al., 2005; Berntsen et al., 2005).

The increase in $\mathrm{CH}_{4}$ concentrations in turn causes a longterm increase in ozone (Wild et al., 2001), on the time scale of the perturbation lifetime of $\mathrm{CH}_{4}$. For a sustained decrease in $\mathrm{NO}_{\mathrm{x}}$ emissions, this long-term ozone increase will partially counteract the direct short-term ozone decrease. While the long-term increase in ozone has been shown to be important for ozone radiative forcing, it also influences surface air quality; for a $20 \%$ decrease in global anthropogenic $\mathrm{NO}_{\mathrm{x}}$ emissions, the long-term increase in ozone counteracts the short-term ozone decrease by $6-14 \%$ for populationweighted ozone air quality metrics (West et al., 2007a). In contrast, reductions in global $\mathrm{CO}$ emissions cause a net increase in $\mathrm{OH}$, which causes $\mathrm{CH}_{4}$ to decrease, leading to a long-term decrease in ozone in addition to the short-term decrease. Global reductions in anthropogenic NMVOC emissions cause nearly negligible effects on $\mathrm{CH}_{4}$ and the longterm change in ozone, in comparison with short-term ozone changes (West et al., 2007a). Reductions of $\mathrm{NO}_{\mathrm{x}}$ from four different world regions have been shown to cause long-term ozone increases that are comparable to the direct short-term ozone decreases due to inter-continental transport, while combinations of $\mathrm{NO}_{\mathrm{x}}, \mathrm{NMVOC}$, and $\mathrm{CO}$ reductions have much smaller long-term influences due to compensating effects on $\mathrm{OH}$ and $\mathrm{CH}_{4}$ (Fiore et al., 2009).

The companion to this paper (West et al., 2009) evaluates the effects of $10 \%$ reductions in anthropogenic $\mathrm{NO}_{\mathrm{x}}$ emissions from each of nine world regions on the long-range transport of ozone air pollution, considering only the direct short-term effects on ozone. In this paper, we use those same simulations to evaluate the long-term changes in surface ozone air quality through resulting changes in $\mathrm{CH}_{4}$, quantifying the effects of $\mathrm{NO}_{\mathrm{x}}$ reductions on $\mathrm{CH}_{4}$ and longterm ozone for each world region. We then present the sum of the short-term and long-term changes in surface ozone air quality - the net steady-state change for sustained $\mathrm{NO}_{\mathrm{x}}$ reductions - and its importance for the ultimate effect on the long-range transport of ozone between all nine world regions. We likewise evaluate the effects of simultaneous reductions in emissions of $\mathrm{NO}_{\mathrm{x}}, \mathrm{NMVOCs}$, and $\mathrm{CO}$ from three world regions, on $\mathrm{CH}_{4}$ and long-term surface ozone.

In addition, ground-level ozone has been associated with several health impairments, and with premature human mortality in a large number of epidemiologic daily time series studies (Levy et al., 2001, 2005; Thurston and Ito, 2001; Bell et al., 2004, 2005; Gryparis et al., 2004; HEI International Scientific Oversight Committee, 2004; Ito et al., 2005; Bell and Dominici, 2006; National Research Council, 2008). These effects on human health generally have been the main motivator for ozone air quality regulations. However, the influence of inter-continental ozone transport on human health has not been investigated for multiple source-receptor pairs.
We therefore evaluate the effects of regional reductions in $\mathrm{NO}_{\mathrm{x}}$ emissions on premature human mortality due to ozone, both within each of the nine source regions and due to interregional transport for all source-receptor pairs. We first present the methods of estimating the long-term changes in ozone via $\mathrm{CH}_{4}$, and the importance of this long-term influence on the net steady-state change in inter-continental ozone transport. Then we present methods of assessing changes in premature human mortality due to changes in ozone, and the avoided mortalities for each world region, for both the shortterm change in ozone air quality and the steady-state change.

\section{Effects of precursor emission reductions on steady- state ozone air quality}

We use the same set of MOZART-2 (Horowitz et al., 2003) simulations that was presented previously by Naik et al. (2005) and the companion to this paper (West et al., 2009), and analyze them here for their effects on long-term changes in surface ozone via changes in atmospheric $\mathrm{CH}_{4}$. These simulations were conducted using meteorology from the middle atmosphere version of the Community Climate Model (MACCM3) at $2.8^{\circ}$ by $2.8^{\circ}$ horizontal resolution, and with emissions for the base simulation that correspond to the early 1990s. Regional emission sensitivity simulations were conducted by removing $10 \%$ of ground-level anthropogenic $\mathrm{NO}_{\mathrm{x}}$ emissions in each of nine world regions, as defined by Naik et al. (2005) and West et al. (2009), and labeled in Table 1. Three additional simulations considered the simultaneous removal of $10 \%$ of anthropogenic $\mathrm{NO}_{\mathrm{x}}$, NMVOCs, and CO in NA, EU, and SE. Emissions have changed since the early 1990s, with likely decreases in anthropogenic ozone precursor emissions from NA, EU, and FSU, and increases elsewhere, particularly in EA (West et al., 2009). This change in emissions will affect our estimates of the change in inter-continental transport and of long-term changes in ozone from $10 \%$ reductions, and are likely less important for the changes per unit change in emissions.

Long-term changes in ozone due to changes in $\mathrm{CH}_{4}$ concentrations are assessed following the methods detailed in West et al. (2007a) and Fiore et al. (2009). These methods are based on Fuglestvedt et al. (1999) and Naik et al. (2005), but differ to account for the spatial and temporal response of ozone to changes in $\mathrm{CH}_{4}$. Since the $10 \%$ regional changes in anthropogenic $\mathrm{NO}_{\mathrm{x}}$ emissions are assumed to be sustained in the future, the long-term change in ozone is added to the direct short-term change to give the net change at steady-state. The change in $\mathrm{CH}_{4}$ lifetime is assessed from the simulated change in $\mathrm{OH}$; on this basis, we estimate the steady-state change in $\mathrm{CH}_{4}$ concentration using a $\mathrm{CH}_{4}-\mathrm{OH}$ feedback factor of 1.33, which was diagnosed for MOZART-2 under the same conditions (West et al., 2007a), and is equivalent to the mean of several models (Fiore et al., 2009). We then use a previous simulation in which anthropogenic $\mathrm{CH}_{4}$ emissions 
Table 1. Long-term changes in global annual mean $\mathrm{CH}_{4}$ and surface $\mathrm{O}_{3}$ concentrations, due to $10 \%$ regional reductions in anthropogenic $\mathrm{NO}_{\mathrm{X}}$ emissions.

\begin{tabular}{|c|c|c|c|c|}
\hline Source Region & $\begin{array}{l}\text { Change in } \\
\text { global CH} \mathrm{CH}_{4} \\
\quad(\mathrm{ppb})^{\mathrm{a}}\end{array}$ & $\begin{array}{c}\mathrm{CH}_{4} \text { change per } \\
\mathrm{Tg} \text { decrease in } \\
\mathrm{NO}_{\mathrm{x}} \text { emissions } \\
\left(\mathrm{ppb}\left(\mathrm{TgN} \mathrm{yr}^{-1}\right)^{-1}\right)^{\mathrm{b}}\end{array}$ & $\begin{array}{l}\text { Change in } \\
\text { surface } \mathrm{O}_{3} \\
\quad(\mathrm{ppt})\end{array}$ & $\begin{array}{l}\text { Surface } \mathrm{O}_{3} \text { change } \\
\text { per Tg decrease in } \\
\mathrm{NO}_{\mathrm{x}} \text { emissions } \\
\left(\operatorname{ppt}\left(\mathrm{TgN} \mathrm{yr}^{-1}\right)^{-1}\right)\end{array}$ \\
\hline NA - North America & 4.54 & 5.7 & 11.5 & 14 \\
\hline EU - Europe & 1.30 & 2.7 & 3.3 & 7 \\
\hline FSU - Former Soviet Union & 0.99 & 4.0 & 2.5 & 10 \\
\hline $\mathrm{AF}-$ Africa & 2.73 & 13.7 & 7.0 & 35 \\
\hline IN - India & 1.55 & 13.5 & 3.9 & 34 \\
\hline EA - East Asia & 2.31 & 5.8 & 6.0 & 15 \\
\hline SA - South America & 2.51 & 30.6 & 6.5 & 79 \\
\hline SE - Southeast Asia & 2.49 & 38.0 & 6.3 & 96 \\
\hline AU - Australia & 1.21 & 31.7 & 3.1 & 81 \\
\hline
\end{tabular}

\footnotetext{
${ }^{a}$ Changes in global $\mathrm{CH}_{4}$ from the HTAP model intercomparison (Fiore et al., 2009) for 11 models, divided by 2 (because of the 20\% NO reductions), are for the NA source region: $5.4 \pm 1.4 \mathrm{ppb}$, EU $3.2 \pm 0.8$, IN 3.1 \pm 1.2 , and EA $4.0 \pm 0.8$. The IN region corresponds to the South Asia region of Fiore et al. (2009).

${ }^{\mathrm{b}}$ Changes in global $\mathrm{CH}_{4}$ per unit $\mathrm{NO}_{\mathrm{x}}$ reduction from HTAP are for NA: 7.3 $\pm 2.0 \mathrm{ppb}\left(\mathrm{TgN} \mathrm{yr}^{-1}\right)^{-1}$, EU 4.4 \pm 1.0, IN 14.1 \pm 5.3 , and EA 7.1土1.9.
}

are reduced by $20 \%$ under the same conditions (West et al., 2007a) to give the spatial and temporal change in ozone due to changes in $\mathrm{CH}_{4}$. We scale the ozone change in each grid cell and at each hour under this methane reduction simulation to the change in $\mathrm{CH}_{4}$ at steady state that we calculate for each regional $\mathrm{NO}_{\mathrm{x}}$ reduction case. We add this long-term change in ozone via $\mathrm{CH}_{4}$ to the short-term ozone change simulated directly in the model, to give the net change at steady state. The steady-state ozone is therefore calculated as a full timevarying three-dimensional field, that accounts for the spatial and temporal (hourly, seasonal) distributions of the net steady-state change in ozone. For sustained emission reductions, the net change in ozone will rapidly reflect the shortterm change, and gradually approach the steady-state change with a timescale equal to the 12-year perturbation lifetime of $\mathrm{CH}_{4}$.

Table 1 shows that the $\mathrm{CH}_{4}$ increase is greatest for the $\mathrm{NO}_{\mathrm{x}}$ reduction from NA, the region with the largest absolute change in $\mathrm{NO}_{\mathrm{x}}$ emissions. The greatest $\mathrm{CH}_{4}$ increase per unit $\mathrm{NO}_{\mathrm{x}}$ decrease, however, results in the regions in the tropics and Southern Hemisphere (SE, AU, and SA), with values varying by more than a factor of ten between different regions. These changes in $\mathrm{CH}_{4}$ are roughly $12 \%$ smaller than those reported by Naik et al. (2005) for the same simulations, because we account for $\mathrm{CH}_{4}$ loss processes other than reaction with $\mathrm{OH}$ (losses in the stratosphere and deposition to soil), and we use the $\mathrm{CH}_{4}-\mathrm{OH}$ feedback factor of 1.33 derived from the model rather than the 1.4 recommended by Prather et al. (2001) (see West et al., 2007a). In Table 1, these changes in $\mathrm{CH}_{4}$ are also compared to the results from $20 \%$ regional reductions of $\mathrm{NO}_{\mathrm{x}}$ in the HTAP model intercomparison (Fiore et al., 2009). The changes in $\mathrm{CH}_{4}$ per unit change in $\mathrm{NO}_{\mathrm{x}}$ emissions are smaller for the four regions here than in HTAP, but within one standard deviation for three regions (except for EU).

This greater sensitivity of $\mathrm{OH}$ and $\mathrm{CH}_{4}$ to changes in emissions in tropical regions is in agreement with the finding of a greater change in ozone per ton of $\mathrm{NO}_{\mathrm{x}}$ from tropical and Southern Hemisphere (SH) emissions, which was attributed to a combination of stronger photochemical activity, greater sensitivity due to lower $\mathrm{NO}_{\mathrm{x}}$ concentrations, and more rapid vertical transport that contributes to longer lifetimes for ozone and its precursors (West et al., 2009). These findings also agree with those of Gupta et al. (1998), who show that $\mathrm{OH}$ increases as emissions are redistributed toward tropical regions.

The changes in $\mathrm{CH}_{4}$ drive proportional long-term changes in global surface ozone (Table 1). Again, the $10 \% \mathrm{NO}_{\mathrm{x}}$ reduction in NA increases long-term surface ozone more than any other region, but the tropical and $\mathrm{SH}$ regions have the greatest long-term ozone change per unit change in $\mathrm{NO}_{\mathrm{x}}$. The long-term ozone change will be distributed spatially according to the response of ozone to $\mathrm{CH}_{4}$, which is fairly uniform globally, but with greater influences in the Northern Hemisphere (NH) than $\mathrm{SH}$, and some regions of peak response, such as the Middle East (West and Fiore, 2005; West et al., 2006, 2007a; Fiore et al., 2008). This long-term global change counteracts the more regionally-focused short-term ozone changes.

Figure 1 shows the effect of including this long-term change in ozone, relative to the short-term change; in many regions, the net steady-state change in ozone is substantially smaller than the short-term change. For the global annual average ozone, the long-term surface ozone change offsets the 


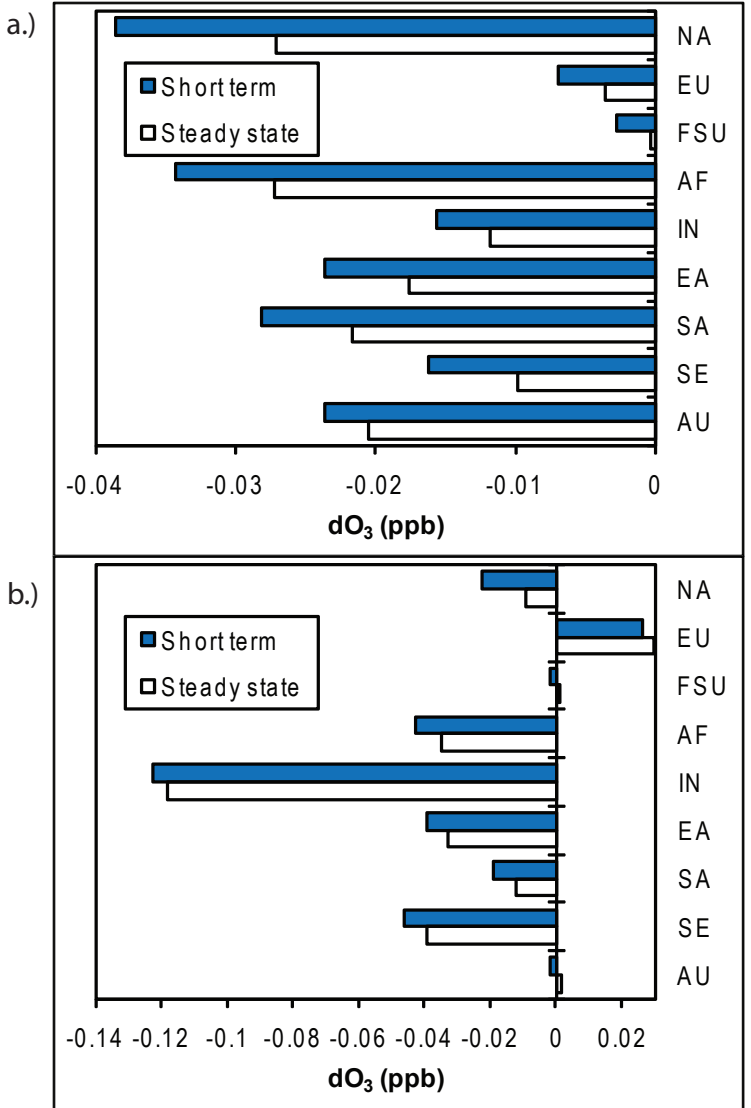

Fig. 1. Change in surface ozone due to $10 \%$ reductions of $\mathrm{NO}_{\mathrm{x}}$ emissions in each of nine regions, for the short term and at steady state, for (a) global annual average ozone, and (b) global population-weighted annual average ozone. Note that the horizontal axes differ in the two plots.

short-term change by between $13 \%$ (for the $\mathrm{NO}_{\mathrm{x}}$ reduction in $\mathrm{AU}$ ) and $89 \%$ (for FSU), depending mainly on the magnitude of the short-term change. Here the short-term change in the global annual average ozone is very small for the $\mathrm{NO}_{\mathrm{x}}$ reductions from EU and FSU because of local increases in ozone as $\mathrm{NO}_{\mathrm{x}}$ is reduced, as discussed by West et al. (2009), particularly in Northern Europe in winter. This local sensitivity causes the global population-weighted ozone to increase for the $10 \% \mathrm{NO}_{\mathrm{x}}$ reduction in $\mathrm{EU}$, while for FSU it is nearly zero. Figure 1 also shows that the long-term ozone has a stronger influence for the spatially-averaged surface ozone than for the population-weighted, relative to the short-term change, as population-weighted results tend to be more heavily influenced by short-term local changes.

The net effect of the regional $\mathrm{NO}_{\mathrm{x}}$ reductions on ozone long-range transport at steady state is in Table 2. We show results in the three-month ozone season for each receptor region, as seasonal concentrations are typically of greatest interest for air quality management, and for a population- weighted metric that emphasizes populated regions and is relevant for human health. For all source-receptor pairs, the steady-state influences are less negative (or more positive) than the short term (West et al., 2009). The source-receptor pairs identified as having the greatest long-range transport influence in the short term also have the greatest influence at steady state (EU on FSU, EA on SE, and EU on AF). While this long-term influence is small in comparison with the short-term effects of a region on itself, it is comparable to the short-term influence for many of the more distant sourcereceptor pairs. Consequently, while the short-term influences for many distant source receptor pairs indicate a reduction in ozone, the net steady-state influence is near zero or an increase in ozone. For example, the influence of AF on EU is a small decrease in ozone in the short term, but a small increase in ozone at steady state (Table 2). Likewise, the steady-state influence of EA on NA is roughly half of the short-term influence.

The difference between short-term and steady-state results is illustrated in Fig. 2, focusing on Europe. Figure 2a shows that for both short-term and steady-state results, the $10 \% \mathrm{NO}_{\mathrm{x}}$ reduction in EU strongly influences FSU, with roughly the same impacts as the influence on EU itself. It also strongly influences AF, while influences on other regions are small. For EU as a source, the differences between shortterm and steady-state results are fairly small, between 3 and 5 ppt. Considering EU as a receptor (Fig. 2b), EU is influenced by the $10 \% \mathrm{NO}_{\mathrm{x}}$ reductions in NA and FSU, with effects that are about $30 \%$ as large as the effect of EU on itself. Here, the differences between the short-term and steady-state results are more variable, from 4 to $18 \mathrm{ppt}$ with the reduction in NA causing the greatest difference, as in Table 1.

When these influences on EU are normalized per unit $\mathrm{NO}_{\mathrm{x}}$ emissions (Fig. 2c), the effect on EU per ton reduced is greater for $\mathrm{NO}_{\mathrm{x}}$ reductions in $\mathrm{FSU}$ than in NA, as the FSU has lower total emissions. For both the short-term and steady-state, the benefit for EU per ton reduced in FSU is about half of the benefit from reductions in EU itself. Likewise, $\mathrm{NO}_{\mathrm{x}}$ reductions in NA are about $20 \%$ as effective per ton in reducing ozone in $\mathrm{EU}$, as $\mathrm{NO}_{\mathrm{x}}$ reductions from $\mathrm{EU}$ itself. In Fig. 2c, the difference between the short-term and steady-state changes per unit $\mathrm{NO}_{\mathrm{x}}$ range widely among the different regions, with much larger differences for SE, SA, and $\mathrm{AU}$, in agreement with Table 1 . The short-term effect per unit $\mathrm{NO}_{\mathrm{x}}$ of SE, SA, and $\mathrm{AU}$ on EU is small, but the steadystate influence is larger and negative because of the large influence per ton on $\mathrm{CH}_{4}$ and long-term ozone. At steady state, therefore, the dominant influence of $\mathrm{NO}_{\mathrm{x}}$ reductions in $\mathrm{SE}$, $\mathrm{SA}$, and $\mathrm{AU}$ on $\mathrm{EU}$ is to cause ozone to increase, via the long-term increase in $\mathrm{CH}_{4}$.

Future studies can estimate the long-term change in ozone due to $\mathrm{NO}_{\mathrm{x}}$ reductions from different world regions directly by using the global annual average surface ozone change per unit $\mathrm{NO}_{\mathrm{x}}$ emissions in the last column of Table 1 , assuming linearity for rather small changes in $\mathrm{NO}_{\mathrm{x}}$. For 
Table 2. Source-receptor matrix of the steady-state change in the 3-month population-weighted average ozone concentration (ppt), for the $10 \%$ regional $\mathrm{NO}_{\mathrm{x}}$ emission reductions. Results are shown for the consecutive three-month period with highest population-weighted ozone for each receptor region, as defined by West et al. (2009). The diagonal, showing the effect of each region on itself, is underlined, while the most negative values off of the diagonal are bold.

\begin{tabular}{rlrrrrrrrrr}
\hline & \multicolumn{1}{c}{ R } & \multicolumn{1}{c}{ NA } & EU & FSU & AF & IN & EA & SA & SE & AU \\
\hline & NA & -498 & $\mathbf{- 4 5}$ & $\mathbf{- 3 3}$ & $-\mathbf{3 0}$ & -29 & 3 & 1 & 2 & 9 \\
& EU & -4 & -189 & $-\mathbf{1 8 0}$ & $-\mathbf{6 9}$ & -9 & -6 & 4 & 1 & 4 \\
& FSU & -11 & $\mathbf{- 5 1}$ & -398 & -13 & -13 & -25 & 3 & 2 & 3 \\
Source & AF & 4 & 2 & -7 & -167 & $-\mathbf{4 1}$ & 6 & -1 & -1 & -10 \\
Region & IN & 1 & 6 & 2 & -1 & -476 & -13 & 2 & -28 & 2 \\
& EA & -9 & 2 & -10 & 1 & 1 & -924 & 5 & $-\mathbf{9 9}$ & 5 \\
& SA & 2 & 11 & 8 & 4 & 4 & 7 & -245 & 2 & -28 \\
& SE & 8 & 12 & 8 & 6 & -7 & $-\mathbf{3 2}$ & -2 & -259 & -4 \\
& AU & 4 & 5 & 4 & 3 & 4 & 3 & -10 & 0 & -176 \\
\hline
\end{tabular}

a.)

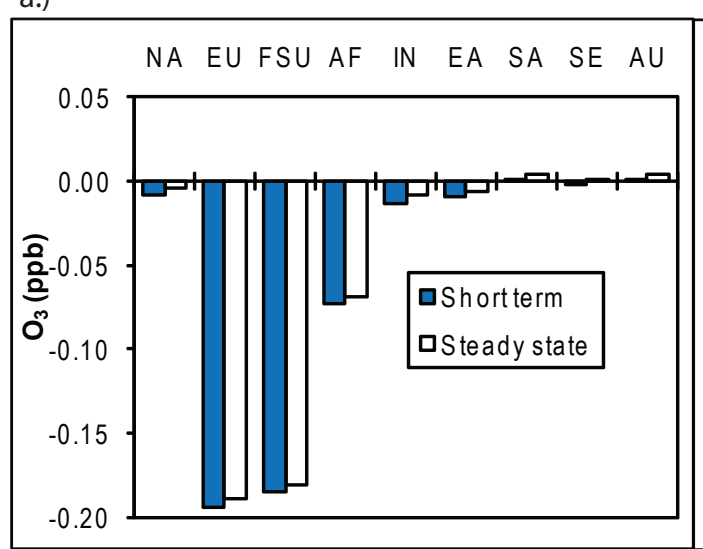

b.)

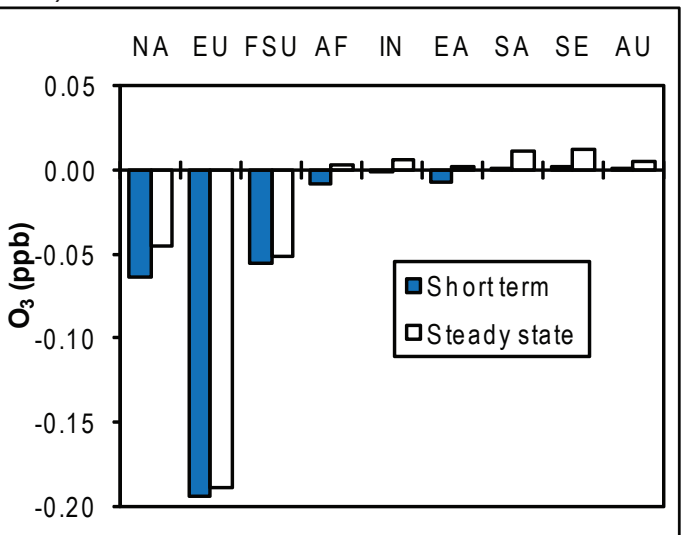

c.)

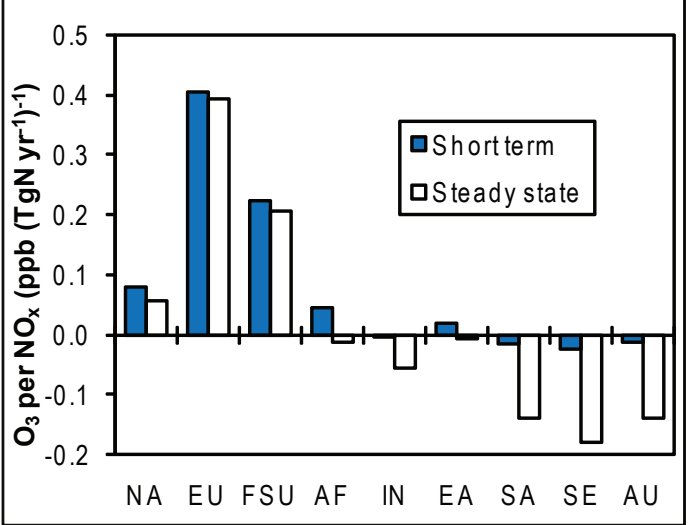

Fig. 2. EU as a source and receptor, using the change in 3-month (JJA) population-weighted $\mathrm{O}_{3}$ in each receptor region, for the short term and steady-state (from West et al. (2009) for short-term results, and Tables 2 and S1 for steady-state results): (a) EU as a source affecting nine receptor regions (reading across Table 2), (b) EU as a receptor affected by nine source regions (reading down Table 2), and (c) EU as a receptor per unit change in $\mathrm{NO}_{\mathrm{x}}$ (reading down Table $\mathrm{S} 1$ ). 
Table 3. Long-term changes in global annual mean $\mathrm{CH}_{4}$ and surface $\mathrm{O}_{3}$ concentrations, due to $10 \%$ regional reductions in anthropogenic emissions of $\mathrm{NO}_{\mathrm{x}}, \mathrm{NMVOCs}$, and $\mathrm{CO}$ combined.

\begin{tabular}{lcccc}
\hline $\begin{array}{l}\text { Source } \\
\text { Region }\end{array}$ & $\begin{array}{c}\text { Change in } \\
\text { global } \mathrm{CH}_{4} \\
(\mathrm{ppb})\end{array}$ & $\begin{array}{c}\mathrm{CH}_{4} \text { change from 10\% } \\
\text { NMVOC and CO } \\
\text { reductions (ppb) }\end{array}$ & $\begin{array}{c}\text { Change in } \\
\text { surface } \mathrm{O}_{3} \\
(\mathrm{ppt})\end{array}$ & $\begin{array}{c}\text { Surface } \mathrm{O}_{3} \text { change from } \\
10 \% \mathrm{NMVOC}^{\mathrm{N}} \text { and CO } \\
\text { reductions }(\mathrm{ppt})^{\mathrm{a}}\end{array}$ \\
\hline NA & 2.30 & -2.23 & 5.8 & -5.7 \\
EU & -0.13 & -1.44 & -0.4 & -3.7 \\
SE & 1.81 & -0.68 & 4.7 & -1.6 \\
\hline
\end{tabular}

a Inferred as the difference between the $10 \%$ reduction of $\mathrm{NO}_{\mathrm{x}}, \mathrm{NMVOCs}$, and $\mathrm{CO}$, and only reducing $\mathrm{NO}_{\mathrm{x}}\left(\mathrm{Table}_{1}\right)$.

Table 4. Source-receptor matrix of the steady-state change in the 3-month population-weighted average ozone concentration (ppt), for the $10 \%$ regional emission reductions of $\mathrm{NO}_{\mathrm{x}}, \mathrm{NMVOCs}$, and CO.

\begin{tabular}{|c|c|c|c|c|c|c|c|c|c|c|}
\hline & & \multicolumn{9}{|c|}{ Receptor Region } \\
\hline & & NA & EU & FSU & $\mathrm{AF}$ & IN & EA & SA & SE & $\mathrm{AU}$ \\
\hline Source & NA & -660 & -104 & -70 & -78 & -72 & -12 & -10 & -23 & -1 \\
\hline Region & EU & -30 & -407 & -240 & -134 & -40 & -18 & -2 & -21 & -2 \\
\hline & $\mathrm{SE}$ & 2 & $\overline{6}$ & 4 & -2 & -19 & -43 & -10 & -296 & -12 \\
\hline
\end{tabular}

example, an emission reduction program that would reduce $\mathrm{NO}_{\mathrm{x}}$ emissions from $\mathrm{NA}$ by $1 \mathrm{TgN} \mathrm{yr}^{-1}$ (sustained into the future) would cause a long-term global increase in the annual average surface ozone of about $14 \mathrm{ppt}$; a reduction in SE would increase ozone by about $96 \mathrm{ppt}$. Future studies interested in considering the inter-regional influences of the long-term changes in ozone can likewise use Table S2, see http://www.atmos-chem-phys.net/9/6095/2009/ acp-9-6095-2009-supplement.pdf, which includes the spatial distribution of the long-term ozone response to $\mathrm{CH}_{4}$. Applications of these results should bear in mind that other models may give different changes in $\mathrm{CH}_{4}$ and long-term surface ozone (Fiore et al., 2009), and that the responses to large emission changes may not be proportional (Wu et al., 2009). The uncertainty in the long-term surface ozone change can be given by the combination of uncertainties in the $\mathrm{CH}_{4}$ change $( \pm 20-40 \%)$ and the change in global ozone with respect to $\mathrm{CH}_{4}( \pm 20 \%)$, estimated for the several models in the HTAP model intercomparison (Fiore et al., 2009).

Table 3 shows the effects of $10 \%$ reductions of anthropogenic emissions of $\mathrm{NO}_{\mathrm{x}}, \mathrm{NMVOCs}$, and $\mathrm{CO}$ on the longterm changes in $\mathrm{CH}_{4}$ and surface ozone concentration, for three source regions. Relative to only reducing $\mathrm{NO}_{\mathrm{x}}$, reducing three precursors simultaneously creates compensating influences, so the changes in $\mathrm{CH}_{4}$ are smaller than in Table 1 . For the simultaneous reductions from EU, the decrease in $\mathrm{CH}_{4}$ caused by the NMVOC and $\mathrm{CO}$ reductions outweighs the increase from reducing $\mathrm{NO}_{\mathrm{x}}$, for a net decrease in $\mathrm{CH}_{4}$. In contrast, the simultaneous reductions from NA and $\mathrm{SE}$ cause a net increase in $\mathrm{CH}_{4}$. This difference arises mainly from the different chemical sensitivities in these regions. If we divide the total $\mathrm{CH}_{4}$ change attributed to the change in NMVOC and $\mathrm{CO}$ emissions by the NMVOC and CO reductions individually (not shown) we find that there is much less variance among these three regions for the $\mathrm{CH}_{4}$ change due to NMVOCs and $\mathrm{CO}$, than for $\mathrm{NO}_{\mathrm{x}}$. The simultaneous reduction in EU therefore causes $\mathrm{CH}_{4}$ to decrease mainly because of a lower sensitivity for the $\mathrm{NO}_{\mathrm{x}}$ reduction in EU, relative to the other regions (Table 1).

Table 3 then presents the global long-term annual average surface ozone changes resulting from the changes in $\mathrm{CH}_{4}$. In Table 4, we show the source-receptor matrix for the net steady-state change in ozone for the simultaneous $\mathrm{NO}_{\mathrm{x}}$, NMVOC and CO reductions. Because the long-term change is very nearly zero for the simultaneous EU reductions (Table 3), there is very little difference from the direct shortterm reduction for EU (West et al., 2009). For the simultaneous reductions in NA and SE, the steady-state results are slightly more negative than the short-term results, but these differences between the short-term and steady-state results are much smaller than when only $\mathrm{NO}_{\mathrm{x}}$ reductions are considered (Table 2). Similarly, Fiore et al. (2009) found that reducing $\mathrm{NO}_{\mathrm{x}}$, NMVOC and $\mathrm{CO}$ emissions in four world regions by $20 \%$ causes compensating changes to $\mathrm{OH}$ and $\mathrm{CH}_{4}$, for little net change in surface ozone; reducing $\mathrm{NO}_{\mathrm{x}}$ and $\mathrm{CO}$ individually causes more marked long-term ozone changes. 


\section{Effects of regional emission reductions on premature human mortality}

Here we assess the effects of inter-continental ozone transport on the incidence of premature human mortality, using the relationships between ozone concentration and mortality from epidemiologic daily time-series studies. We employ the methods used previously by West et al. $(2006,2007 \mathrm{~b})$ to assess the global effects of ozone concentration changes on mortality, consistent with methods recommended by the National Research Council (2008). We use the ozone-mortality relationship derived from a daily time-series study that uses a large database of 95 cities in the United States (US) (Bell et al., 2004). This ozone-mortality relationship (given by $\beta$ ) is smaller than reported by recent meta-analyses (Bell et al., 2005; Ito et al., 2005; Levy et al., 2005), and is chosen for its large dataset with no possibility of publication bias. While the relationship between ozone and mortality has not been investigated thoroughly in developing nations, similar relationships have been found in other studies in the US (Levy et al., 2001; Thurston and Ito, 2001; Bell and Dominici, 2006), Europe (Gryparis et al., 2004), and some of the few available studies in developing nations (Borja-Aburto, 1998; Kim et al., 2004; O’Neill et al., 2004; HEI International Scientific Oversight Committee, 2004). While ozone may cause other human health effects, we estimate mortalities because it often dominates over other health effects when monetized, and because global data on baseline incidence rates are lacking for other health effects.

We estimate the change in total non-accidental mortality in each grid cell on each day, using the change in 24-h average ozone concentration (for both the short-term and steady-state ozone changes), using a value for $\beta$ of $0.52 \%$ (95\% posterior interval of $0.27-0.77 \%$ ) excess nonaccidental mortalities per $10 \mathrm{ppb}$ change in 24-h ozone (Bell et al., 2004). Available epidemiologic studies do not clearly show a low-concentration threshold below which changes in ozone have no effect on mortality (Bell and Dominici, 2006; National Research Council, 2008); here we assume a lowconcentration threshold for ozone of $25 \mathrm{ppb}$, as in previous studies (West et al., 2006, 2007b).

The global distribution of population in 2003 is taken from the LandScan database (Oak Ridge National Laboratory, 2005), and mapped onto the MOZART- 2 modeling grid. Non-accidental baseline mortality rates are taken from the World Health Organization (2004) for each of 14 world regions, which are also mapped onto the modeling grid, and vary between $0.416 \%$ per year (percentage of the population that dies of non-accidental causes in a year) for the Eastern Mediterranean-B region (which includes Saudi Arabia) and $1.554 \%$ per year for the Africa-E region (which includes Ethiopia) (see West et al., 2006). Estimates of avoided mortalities are uncertain to $\pm 50 \%$ due to the uncertainty in $\beta$ from Bell et al. (2004), or potentially greater uncertainty considering the literature as a whole. Other major sources of uncertainty result from the low-concentration threshold, the application of the ozone-mortality relationship in less industrialized nations, and the uncertainty in the modeled ozone response itself; these uncertainties have been explored elsewhere (West et al., 2006, 2007b). Here we emphasize the relative changes in mortality in different receptor regions, due to regional emission reductions and inter-regional transport, rather than the total numbers of estimated mortalities. We test the sensitivity of our major findings for mortalities due to only cardiovascular and respiratory (CR) mortalities, and for alternative low-concentration thresholds.

\subsection{Results}

We first show results for direct short-term changes in ozone, as these would be realized immediately, while the steadystate changes in ozone would be experienced by a future population. Table 5 shows the effects of regional $\mathrm{NO}_{\mathrm{x}}$ reductions on the avoided premature all-cause mortalities per year resulting from short-term changes in ozone in each region, as a source-receptor matrix. The avoided mortalities estimated in each region are influenced by the population, the baseline mortality rate, and the daily changes in ozone in each grid cell, for days above the threshold. The results highlight the receptor regions $\mathrm{EA}, \mathrm{IN}$, and $\mathrm{AF}$, as these regions have the highest population, and AF has the highest baseline mortality rate in the world. The results show that the $10 \%$ reduction in $\mathrm{NO}_{\mathrm{x}}$ emissions in IN causes the greatest number of avoided mortalities, with $93 \%$ of that benefit occurring in IN itself. Large numbers of avoided mortalities result in $\mathrm{IN}$ from $\mathrm{NO}_{\mathrm{x}}$ reductions within the same region because of the high population density and because it has the largest decrease in the population-weighted annual average ozone (Fig. 1b); $\mathrm{NO}_{\mathrm{x}}$ reductions in $\mathrm{IN}$ also reduce ozone throughout the year, while reductions in NA, EU, FSU, and EA increase the population-weighted ozone in the $\mathrm{NH}$ winter (West et al., 2009).

Decreases in $\mathrm{NO}_{\mathrm{x}}$ from many regions cause substantial reductions in mortalities in other regions. In particular, the $10 \% \mathrm{NO}_{\mathrm{x}}$ reductions in NA, AF, EA, and SE all have substantial influences on mortality in IN. The greatest interregional influence on mortality is from the $10 \%$ reduction in EU on mortalities in AF, where most of those avoided mortalities are in the Middle East and North Africa.

Interestingly, the $\mathrm{NO}_{\mathrm{x}}$ reduction in NA causes a substantial number of avoided premature mortalities in the regions $\mathrm{AF}$, EU, IN, and EA, such that more avoided premature mortalities result outside of NA than within. Similarly, the $\mathrm{NO}_{\mathrm{x}}$ reductions in EU, FSU, and AU also cause a greater number of avoided premature mortalities outside of these source regions than within, consistent with other results for Europe using a different atmospheric model (Duncan et al., 2008). This results in part because the populations influenced elsewhere in the $\mathrm{NH}$ are much greater than within the NA, EU and FSU source regions. Similarly, AU has a small population within 


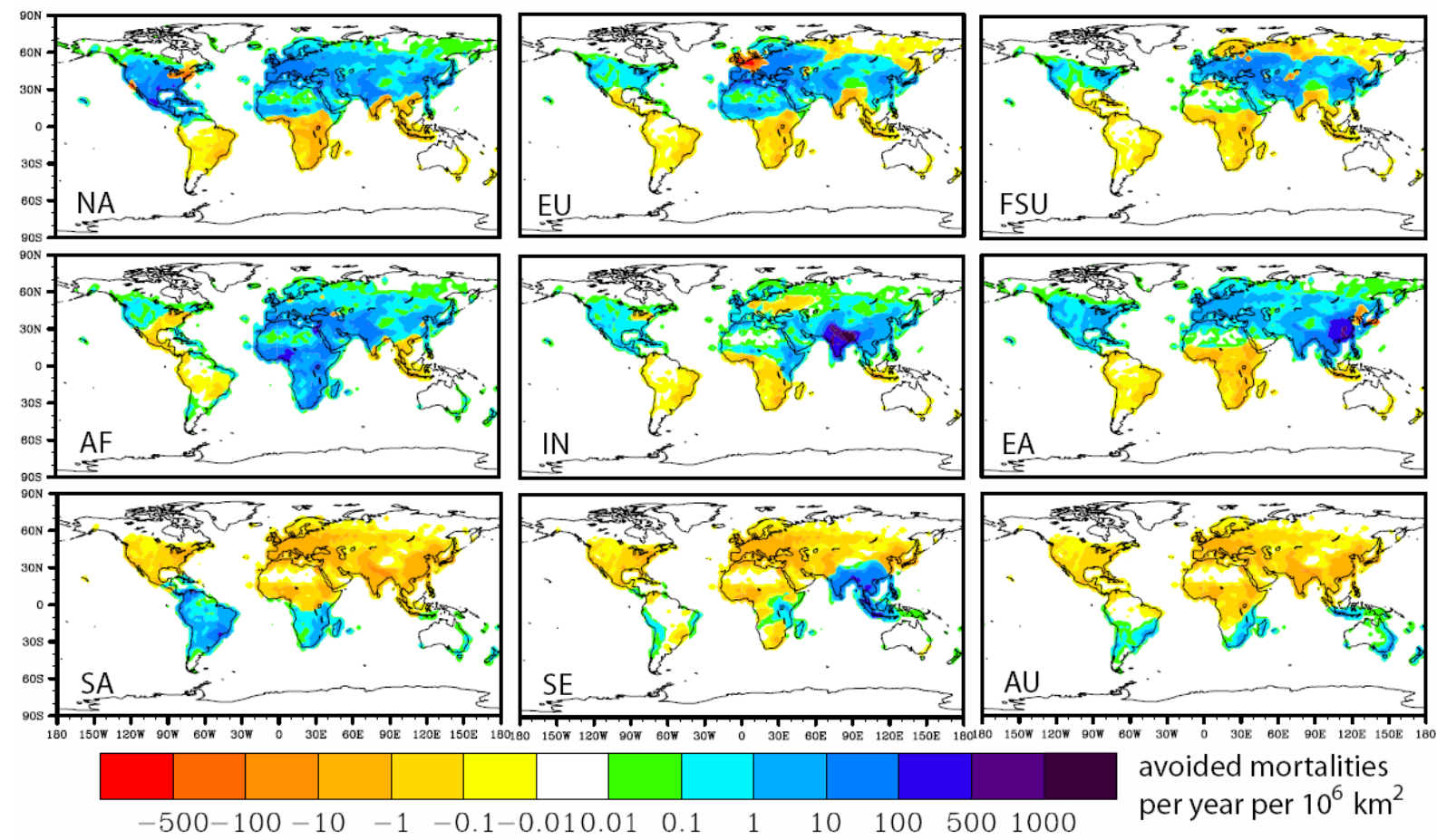

Fig. 3. Avoided premature moralities from $10 \%$ anthropogenic $\mathrm{NO}_{\mathrm{x}}$ reductions in each of nine world regions, at steady state and using a low-concentration threshold of $25 \mathrm{ppb}$.

that region, but larger populations potentially exposed in AF, SE, and SA. Further, the regions NA, EU, and FSU all contain areas where $\mathrm{NO}_{\mathrm{x}}$ reductions cause increases in ozone, particularly in populated areas in winter, which decreases the number of intra-regional avoided mortalities. While some winter days may be below the low-concentration threshold, therefore having no effect on the estimated avoided mortalities, many such days are above this threshold. The reduction in EU is actually estimated to increase mortalities within that same region, as the population-weighted annual average concentration increases (Fig. 1b) due to an increase in ozone in Northern Europe and a decrease near the Mediterranean Sea. Summing over the $10 \%$ reductions in all nine regions, we find that the total inter-regional avoided mortalities are substantial: 2600 per year, or $31 \%$ of the total avoided mortalities.

In Table 6, we normalize the avoided premature mortalities per unit $\mathrm{NO}_{\mathrm{x}}$ emissions reduced in each source region. As in Table S1, estimating the reduction per unit $\mathrm{NO}_{\mathrm{x}}$ emissions emphasizes source regions in the tropics and $\mathrm{SH}$, due to the greater sensitivity to $\mathrm{NO}_{\mathrm{x}}$ reductions. The results show that an average ton of $\mathrm{NO}_{\mathrm{x}}$ reduced in IN results in the greatest reduction in mortalities, where the great majority of these avoided mortalities are within IN itself. Reducing emissions in SE also has a large effect on the avoided premature mortalities per unit $\mathrm{NO}_{\mathrm{x}}$, with large impacts on avoided mortalities in the heavily populated regions IN and EA.
Table 7 shows that the simultaneous reduction of $\mathrm{NO}_{\mathrm{x}}$, NMVOCs and $\mathrm{CO}$ causes many more avoided premature mortalities than when reducing $\mathrm{NO}_{\mathrm{x}}$ alone. The conclusion that $\mathrm{NO}_{\mathrm{x}}$ reductions in NA and EU cause more avoided mortalities outside of these regions than within also holds when reducing all three precursors. These results are compared with those of Anenberg et al. (2009) who assess mortality for simulations from the HTAP multimodel intercomparison (Fiore et al., 2009), where we use the same conditions and definitions of receptor regions as in that study (Table S3). Results show fewer intra-regional and inter-regional avoided mortalities in the present study, which is attributed mainly to the lower sensitivity of MOZART-2 to changes in precursor emissions than the HTAP multimodel mean (West et al., 2009), as the two studies use very similar methods to assess mortalities for a given change in ozone concentration.

Figure 3 and Tables 8, S4, and S5 show results for avoided mortalities at steady state. We calculate the steady-state avoided mortalities using the present-day population, for ease of comparison with the short-term results; since population is expected to grow, the ultimate inter-continental effects on mortality may be greater than represented here, particularly for tropical receptor regions. Figure 3 shows that at steady state, avoided mortalities are widespread in the $\mathrm{NH}$ for the $10 \% \mathrm{NO}_{\mathrm{x}}$ reductions from NA, EU, FSU, IN, and EA. These reductions also result in small increases in mortality in the $\mathrm{SH}$, due to the long-term ozone increase. Similarly, 
Table 5. Avoided premature non-accidental mortalities per year due to reductions in $10 \%$ of anthropogenic $\mathrm{NO}_{\mathrm{x}}$ emissions from each region, for short-term changes in ozone.

\begin{tabular}{|c|c|c|c|c|c|c|c|c|c|c|c|}
\hline & & \multicolumn{10}{|c|}{ Receptor Region } \\
\hline & & NA & EU & FSU & $\mathrm{AF}$ & IN & EA & SA & SE & $\mathrm{AU}$ & Global \\
\hline & NA & 251 & 148 & 59 & 162 & 133 & 106 & 11 & 7 & 0 & 876 \\
\hline & EU & $\overline{12}$ & -289 & 89 & 250 & 39 & 54 & 0 & 2 & 0 & 158 \\
\hline & FSU & 12 & 53 & $\underline{50}$ & 67 & 62 & 89 & 0 & 1 & 0 & 333 \\
\hline Source & $\mathrm{AF}$ & 12 & 49 & $\overline{36}$ & $\underline{938}$ & 134 & 58 & 4 & 5 & 5 & 1238 \\
\hline \multirow[t]{6}{*}{ Region } & IN & 13 & 13 & 10 & $\overline{53}$ & $\underline{3012}$ & 80 & 1 & 56 & 0 & 3238 \\
\hline & EA & 38 & 45 & 25 & 34 & $\overline{107}$ & $\underline{1154}$ & 0 & 124 & 0 & 1527 \\
\hline & SA & 3 & -1 & 0 & 33 & 9 & $\overline{-1}$ & $\underline{203}$ & 3 & 1 & 251 \\
\hline & SE & 3 & 1 & 1 & 29 & 149 & 100 & $\overline{4}$ & $\underline{417}$ & 0 & 704 \\
\hline & $\mathrm{AU}$ & -1 & -1 & 0 & 7 & -2 & -2 & 5 & 7 & $\underline{7}$ & 20 \\
\hline & Global $^{\mathrm{a}}$ & & & & & & & & & & 8344 \\
\hline
\end{tabular}

${ }^{\text {a }}$ Global is the sum of $10 \%$ reductions in each region, and may differ from the results of a simulation where anthropogenic $\mathrm{NO}_{\mathrm{x}}$ is reduced by $10 \%$ globally.

Table 6. Avoided premature mortalities (Table 5) per year per Tg reduction in $\mathrm{NO}_{\mathrm{x}}$ emissions (mortalities $\left.\left(\mathrm{TgN}^{-1}\right)^{-1}\right)$, for short-term changes in ozone.

\begin{tabular}{|c|c|c|c|c|c|c|c|c|c|c|c|}
\hline & & \multicolumn{10}{|c|}{ Receptor Region } \\
\hline & & NA & EU & FSU & $\mathrm{AF}$ & IN & EA & SA & SE & $\mathrm{AU}$ & Global \\
\hline & NA & $\underline{32}$ & 18 & 7 & 20 & 17 & 13 & 1 & 1 & 0 & 110 \\
\hline & EU & $\overline{3}$ & -60 & 18 & 52 & 8 & 11 & 0 & 4 & 0 & 33 \\
\hline & FSU & 5 & $\overline{21}$ & $\underline{20}$ & 27 & 25 & 36 & 0 & 0 & 0 & 135 \\
\hline Source & $\mathrm{AF}$ & 6 & 25 & $\overline{18}$ & $\underline{472}$ & 68 & 29 & 2 & 0 & 0 & 623 \\
\hline \multirow[t]{5}{*}{ Region } & IN & 12 & 11 & 8 & 46 & 2621 & 70 & 1 & 3 & 0 & 2818 \\
\hline & EA & 10 & 11 & 6 & 8 & 27 & 290 & 0 & 49 & 0 & 383 \\
\hline & SA & 4 & -1 & 0 & 40 & 12 & -1 & 248 & 31 & 1 & 306 \\
\hline & $\mathrm{SE}$ & 5 & 2 & 1 & 44 & 227 & 152 & 6 & 637 & 0 & 1076 \\
\hline & $\begin{array}{l}\text { AU } \\
\text { Global }^{\mathrm{a}}\end{array}$ & -1 & -2 & -1 & 18 & -6 & -4 & 13 & 17 & $\underline{19}$ & $\begin{array}{r}52 \\
345\end{array}$ \\
\hline
\end{tabular}

${ }^{\mathrm{a}}$ Here, global is the average avoided mortalities per unit $\mathrm{NO}_{\mathrm{x}}$ reduced globally, taken as the sum of avoided mortalities in all nine regions, divided by $10 \%$ of the global anthropogenic $\mathrm{NO}_{\mathrm{x}}$ emissions.

reductions from $\mathrm{SA}, \mathrm{SE}$, and $\mathrm{AU}$ decrease mortality in the $\mathrm{SH}$, but increase mortality in much of the $\mathrm{NH}$, as the longterm ozone increase dominates in the $\mathrm{NH}$.

Comparing Table 8 at steady state with the short-term results (Table 5), we see that the results are similar, but with fewer avoided mortalities. Because the long-term ozone increase is globally widespread, the largest differences between the short-term and steady-state results are in the interregional mortalities, which decrease substantially from 2600 per year in Table 5 to 1432 here (20\% of the total), accounting for most of the difference in total mortalities between the two cases. Because of the large effect on longterm ozone from emissions in the tropics and $\mathrm{SH}$, we see that the $\mathrm{NO}_{\mathrm{x}}$ reduction from $\mathrm{AU}$ causes a net increase in mortalities at steady state, mainly because of mortality increases in highly populated regions of the NH. Figure 3 also shows localized increases in mortalities within the source regions of NA, EU, FSU, and EA, which are generally caused by local increases in ozone, as discussed earlier, and are often strongest in winter.

\subsection{Sensitivity}

While the overall uncertainty in estimates of mortality is substantial, and influenced by several assumptions and parameters (West et al., 2007b), we are most interested here in the uncertainties and assumptions important for the relative numbers of avoided mortalities among the source-receptor pairs. In particular, we analyze the conclusion that $10 \%$ reductions in anthropogenic $\mathrm{NO}_{\mathrm{x}}$ emissions in NA, EU, and FSU cause more avoided premature mortalities outside of these source regions than within. 
Table 7. Avoided premature mortalities per year due to reductions in $10 \%$ of anthropogenic $\mathrm{NO}_{\mathrm{x}}$, $\mathrm{NMVOCs}$, and CO emissions from each region, for short-term changes in ozone.

\begin{tabular}{rlrrrrrrrrrr}
\hline & \multicolumn{1}{c}{ NA } & EU & FSU & AF & IN & EA & SA & SE & AU & Global \\
\hline Source & NA & $\underline{501}$ & $\mathbf{2 5 9}$ & 109 & $\mathbf{3 1 8}$ & $\mathbf{2 4 6}$ & $\mathbf{2 4 7}$ & 15 & 22 & 0 & 1719 \\
Region & EU & 52 & $\underline{83}$ & 179 & $\mathbf{4 9 2}$ & 124 & $\mathbf{2 1 7}$ & 2 & 15 & 0 & 1164 \\
& SE & 10 & 9 & 5 & 64 & $\mathbf{2 0 6}$ & 136 & 7 & $\underline{467}$ & 0 & 905 \\
\hline
\end{tabular}

Table 8. As Table 5, but at steady state.

\begin{tabular}{rlrrrrrrrrrr}
\hline & & & \multicolumn{1}{c}{ Receptor Region } & \multicolumn{2}{c}{} \\
& & NA & EU & FSU & AF & IN & EA & SA & SE & AU & Global \\
\hline \multirow{5}{*}{ Source } & NA & $\underline{231}$ & $\mathbf{1 1 7}$ & 44 & $\mathbf{7 3}$ & 59 & 49 & 4 & -6 & 0 & 571 \\
& EU & 7 & -298 & $\mathbf{8 4}$ & $\mathbf{2 2 5}$ & 18 & 37 & -2 & -2 & 0 & 70 \\
& FSU & 7 & 46 & $\underline{47}$ & 48 & 46 & $\mathbf{7 7}$ & -2 & -2 & 0 & 267 \\
& AF & 0 & 31 & 27 & $\underline{885}$ & $\mathbf{9 0}$ & 24 & 0 & -3 & 0 & 1055 \\
& IN & 7 & 2 & 5 & 23 & 2987 & 61 & -42 & 52 & 0 & 3134 \\
& EA & 28 & 29 & 17 & -11 & $\mathbf{6 9}$ & $\underline{1125}$ & -3 & $\mathbf{1 1 8}$ & 0 & 1371 \\
& SA & -8 & -18 & -8 & -16 & -32 & -32 & $\underline{199}$ & -4 & 1 & 82 \\
& SE & -8 & -15 & -7 & -20 & $\mathbf{1 0 8}$ & $\mathbf{6 9}$ & 0 & $\underline{410}$ & 0 & 537 \\
& AU & -6 & -9 & -4 & -17 & -22 & -17 & 3 & 3 & $\underline{7}$ & -62 \\
& Global & & & & & & & & & & 7025 \\
\hline
\end{tabular}

An important assumption for the relative numbers of mortalities within and outside of the source region is that the concentration-response relationship is applicable globally. As discussed earlier, the concentration-response relationship is estimated in one large study in the US, which is broadly consistent with other studies in North America and Europe. Fewer studies are available in less industrialized nations for comparison, but the large difference in general causes of death in less industrialized nations suggests that these concentration-response relationships may be inaccurate elsewhere.

As a sensitivity analysis, we consider only the effects of ozone on CR mortality, since CR causes are the most plausible means by which ozone might affect mortality. In less industrialized nations, baseline CR mortality rates are generally much lower than the baseline non-accidental mortality rate, since a large fraction of the population dies from other causes. We estimate CR mortality using the appropriate $\mathrm{CR}$ baseline mortality rate for each of the 14 world regions (World Health Organization, 2004), and the $\beta$ for CR mortality from Bell et al. (2004). In Table 9, the global avoided CR mortalities decrease relative to the total mortality base case, for the $10 \% \mathrm{NO}_{\mathrm{x}}$ reductions from NA, EU, and FSU, as a result of the lower baseline CR mortality rates. Here we show mortality estimates at steady state, since the steadystate results have greater within-region avoided mortalities as a fraction of the total (Table 8). For all three regions, more avoided CR mortalities occur outside of the source region than within.
Second, we consider the uncertainty in the lowconcentration threshold, below which changes in ozone are assumed to not affect mortality. Reductions in $\mathrm{NO}_{\mathrm{x}}$ from both NA and EU cause some local increases in ozone near areas with large concentrations of population and emissions (Fig. 3). Since many of these increases occur on days with low ozone concentrations and in winter, raising the threshold would cause a smaller increase in mortalities in these areas. By raising the threshold from $25 \mathrm{ppb}$ to $40 \mathrm{ppb}$, the avoided mortalities within the source regions increase for all three regions in Table 9. For EU and FSU, the conclusion holds that there is a greater reduction in mortality outside of the source region than within. For NA, however, the avoided mortalities within the source region exceed those outside of the source region, when using the $40 \mathrm{ppb}$ threshold.

Similarly, rather than increasing the threshold, we exclude the winter months, considering only seven months from April through October. Some analyses of ozone mortality in NH temperate regions consider only the summer months when ozone pollution is highest. However, these same seasonal patterns for ozone do not hold globally, particularly in tropical regions. By excluding the winter months, withinregion mortalities increase relative to the base case (Table 9), and the conclusion that most avoided mortalities are outside of EU and FSU still holds. For $\mathrm{NA}$, the $\mathrm{NO}_{\mathrm{x}}$ reduction causes more avoided mortalities within (versus outside of) the source region. 
Table 9. Sensitivity analysis of avoided premature mortalities globally and within the source region (in parenthesis) from $10 \%$ regional $\mathrm{NO}_{\mathrm{x}}$ reductions at steady state, in the base case (from Table 8), and considering cardiovascular and respiratory mortality (CR) only, a low-concentration threshold of $40 \mathrm{ppb}$, and excluding winter (for April-October only).

\begin{tabular}{rlrrrr}
\hline & & Base case & CR only & Threshold 40 ppb & Excluding winter \\
\hline Source & NA & $571(231)$ & $360(130)$ & $534(347)$ & $468(299)$ \\
Region & EU & $70(-298)$ & $38(-190)$ & $609(281)$ & $380(-14)$ \\
& FSU & $267(47)$ & $193(41)$ & $271(95)$ & $426(167)$ \\
\hline
\end{tabular}

\section{Conclusions}

Large-scale changes in emissions of ozone precursors cause direct short-term changes in ozone that affect air quality on inter-continental scales. These changes also cause global long-term changes in ozone via changes in $\mathrm{CH}_{4}$. Here we quantify these long-term effects on surface ozone air quality as a function of the source region, for nine source regions globally. Reductions in $\mathrm{NO}_{\mathrm{x}}$ emissions from all source regions are shown to increase $\mathrm{CH}_{4}$ and ozone in the long term. While the long-term increase in ozone is small compared with the short-term ozone decrease within a source region, it is comparable to many of the short-term inter-regional influences, but opposite in sign. For some source-receptor pairs, the long-term increase is roughly equal to or exceeds the short-term decrease, for a net increase in ozone. For example, the steady-state influence of $\mathrm{NO}_{\mathrm{x}}$ reductions in EA on NA is roughly half of the short-term influence. Decreases in NMVOC and $\mathrm{CO}$ emissions reduce $\mathrm{CH}_{4}$ and cause a decrease in ozone in the long term. Per unit decrease in $\mathrm{NO}_{\mathrm{x}}$ emissions, the long-term increase in ozone is greatest from source regions in the tropics and $\mathrm{SH}$, in some cases more than a factor of ten greater than the long-term increase from reductions in temperate regions of the NH. The dominant influence of $\mathrm{NO}_{\mathrm{x}}$ reductions in tropical and $\mathrm{SH}$ source regions on temperate regions of the $\mathrm{NH}$ is the long-term ozone increase. Our estimates of the long-term ozone increase can be used in future studies to add to the short-term effects of ozone precursor reductions modeled directly on regional scales.

We also estimate the avoided premature mortalities in all world regions due to changes in ozone from regional reductions of precursor emissions. The strongest inter-regional effect on mortality is seen for EU on AF, where most of these avoided mortalities are in the Middle East and North Africa; this is true for short-term and steady-state cases, as well as whether emissions of $\mathrm{NO}_{\mathrm{x}}$ or all three precursors are reduced. For $10 \% \mathrm{NO}_{\mathrm{x}}$ reductions in all regions, we find that $31 \%$ of the total avoided mortalities in the short term are due to inter-regional transport; although the change in ozone within the source region is generally much greater than elsewhere, a much larger population is potentially exposed outside of the source region. The contribution of inter-regional transport decreases to $20 \%$ of total mortalities when the long- term increase in ozone (via $\mathrm{CH}_{4}$ ) is accounted for. Reducing $\mathrm{NO}_{\mathrm{x}}$ emissions from IN is shown to cause the most avoided premature mortalities per ton of $\mathrm{NO}_{\mathrm{x}}$ of any world region, with most of those avoided mortalities occurring within IN itself, due to the high population density and strong sensitivity to changes in $\mathrm{NO}_{\mathrm{x}}$.

Reductions in ozone precursor emissions in EU, NA, and FSU are shown to cause more ozone-related avoided premature mortalities outside of the source region than within, due to both larger relevant populations outside of the source region, and because $\mathrm{NO}_{\mathrm{x}}$ reductions cause ozone to increase in some locations within the source region, mainly in winter. These findings agree with analyses for EU using a different atmospheric model (Duncan et al., 2008), and for EU and NA using a multimodel ensemble mean (Anenberg et al., 2009). This analysis is limited to considering ozone-related mortality; including changes in particulate matter (PM) concentrations due to these precursor reductions may significantly change the results, as PM has been strongly linked with mortality (Pope et al., 2002).

This conclusion that reductions in EU, NA, and FSU cause more avoided mortalities outside of these regions than within is robust over sensitivities to key parameters and assumptions in our mortality estimates, except for NA in some cases considered. It is also subject to uncertainties in estimates of the relative changes in ozone within and outside of the source region, from the atmospheric model. In their multimodel intercomparison, Fiore et al. (2009) find that there is substantial variation between models in their estimated impacts of emission reductions within the source regions, as global models with different emissions have different local sensitivities. Anenberg et al. (2009) show that for this multimodel ensemble, the relative mortalities within versus outside of source regions is strongly influenced by uncertainty in the intra-regional change in ozone among the different models. While a global model is currently the best tool available for addressing long-range transport, estimates of the populationweighted change in concentration within a source region (and mortalities) should be analyzed by regional models at finer scales, that have been tested extensively for local conditions. Further research should also quantify the possible bias from using coarse-resolution global models to estimate health effects. Our assessment of the effects of long-range transport on mortality is also limited by our understanding of the 
mortality effects of ozone, and future research should aim to improve this understanding, particularly in developing nations and at higher ozone concentrations than are commonly observed in the US and Europe.

We show that accounting for the long-term influence of precursors on ozone can change estimates of the net effect on mortality, and may be the dominant influence for more distant source-receptor pairs. For example, reductions of $\mathrm{NO}_{\mathrm{x}}$ in the $\mathrm{SH}$ are expected to generally increase mortalities at steady state in the $\mathrm{NH}$. Because of the long-term global ozone increase resulting from $\mathrm{NO}_{\mathrm{x}}$ reductions, as well as the net increase in radiative climate forcing, ozone air quality management may consider a greater emphasis on reducing NMVOCs, $\mathrm{CO}$, and particularly $\mathrm{CH}_{4}$, alongside reductions in $\mathrm{NO}_{\mathrm{x}}$ (Fiore et al., 2002; West et al., 2007a). Finally, these findings of large health benefits outside of source regions suggest that national or regional assessments of the costs and benefits of air pollutant control actions (such as are conducted routinely by the US Environmental Protection Agency or the European Commission) may significantly underestimate the total human health benefits by not including benefits outside of national or continental boundaries.

Acknowledgements. We thank J. Liu, D. Mauzerall, H. Levy II, and S. Anenberg for helpful conversations. This work was supported by the National Oceanic and Atmospheric Administration.

Edited by: B. N. Duncan

\section{References}

Anenberg, S. C., West, J. J., Fiore, A. M., Jaffe, D. A., Prather, M. J., Bergmann, D., Cuvelier, C., Dentener, F. J., Gauss, M., Hess, P., Jonson, J. E., Lupu, A., MacKenzie, I. A., Marmer, E., Park, R. J., Sanderson, M., Schultz, M., Shindell, D. T., Szopa, S., Vivanco, M. G., Wild, O., and Zeng, G.: Intercontinental Impacts of Ozone Pollution on Human Mortality, Environ. Sci. Technol., submitted, in press, 2009.

Bell, M. and Dominici, F.: Analysis of threshold effects for shortterm exposure to ozone and increased risk of mortality, Epidemiology, 7, S223-S223, 2006.

Bell, M. L., McDermott, A., Zeger, S. L., Samet, J. M., and Dominici, F.: Ozone and short-term mortality in 95 US urban communities, 1987-2000, JAMA-J. Am. Med. Assoc., 292, 23722378, 2004.

Bell, M. L., Dominici, F., and Samet, J. M.: A meta-analysis of time-series studies of ozone and mortality with comparison to the National Morbidity, Mortality, and Air Pollution Study, Epidemiology, 16, 436-445, 2005.

Berntsen, T. K., Fuglestvedt, J. S., Joshi, M. M., Shine, K. P., Stuber, N., Ponater, M., Sausen, R., Hauglustaine, D. A., and Li, L.: Response of climate to regional emissions of ozone precursors: sensitivities and warming potentials, Tellus B, 57, 283-304, 2005.

Borja-Aburto, V. H., Castillejos, M., Gold, D. R., Bierzwinski, S., and Loomis, D.: Mortality and ambient fine particles in south- west Mexico City, 1993-1995, Environ. Health Persp., 106, 849855, 1998.

Duncan, B. N., West, J. J., Yoshida, Y., Fiore, A. M., and Ziemke, J. R.: The influence of European pollution on ozone in the Near East and northern Africa, Atmos. Chem. Phys., 8, 2267-2283, 2008 , http://www.atmos-chem-phys.net/8/2267/2008/.

Fiore, A. M., Jacob, D. J., Field, B. D., Streets, D. G., Fernandes, S. D., and Jang, C.: Linking ozone pollution and climate change: The case for controlling methane, Geophys. Res. Lett., 29(19), 1919, doi:10.1029/2002GL015601, 2002.

Fiore, A. M., West, J. J., Horowitz, L. W., Naik, V., and Schwarzkopf, M. D.: Characterizing the tropospheric ozone response to methane emission controls and the benefits to climate and air quality, J. Geophys. Res., 113, D08307, doi:10.1029/2007JD009162, 2008.

Fiore, A. M., Dentener, F. J., Wild, O., Cuvelier, C., Schultz, M. G., Textor, C., Schulz, M., Atherton, C., Bergmann, D., Bey, I., Carmichael, G., Collins, W. J., Duncan, B. N., Faluvegi, G., Folberth, G., Gauss, M., Gong, S., Hauglustaine, D., Holloway, T., Isaksen, I. S. A., Jacob, D. J., Jonson, J. E., Kaminski, J. W., Keating, T. J., Lupu, A., Marmer, E., Montanaro, V., Park, R. J., Pitari, G., Pringle, K. J., Pyle, J. A., Schroeder, S., Vivanco, M. G., Wind, P., Wojcik, G., Wu, S., and Zuber, A.: Multi-model Estimates of Intercontinental Source-Receptor Relationships for Ozone Pollution, J. Geophys. Res., 114, D04301, doi:10.1029/2008JD010816, 2009.

Forster, P., Ramaswamy, V., Artaxo, P., Berntsen, T., Betts, R., Fahey, D. W., Haywood, J., Lean, J., Lowe, D. C., Myhre, G., Nganga, J., Prinn, R., Raga, G., Schulz, M., and Van Dorland, R.: Changes in Atmospheric Constituents and in Radiative Forcing, in: Climate Change 2007: The Physcial Science Basis, edited by: Solomon, S., Qin, D., Manning, M., Chen, Z., Marquis, M., Averyt, K. B., Tignor, M., and Miller, H. L., Cambridge University Press, New York, USA, 129-234, 2007.

Fuglestvedt, J. S., Berntsen, T. K., Isaksen, I. S. A., Mao, H. T., Liang, X. Z., and Wang, W. C.: Climatic forcing of nitrogen oxides through changes in tropospheric ozone and methane; global 3D model studies, Atmos. Environ., 33, 961-977, 1999.

Gryparis, A., Forsberg, B., Katsouyanni, K., Analitis, A., Touloumi, G., Schwartz, J., Samoli, E., Medina, S., Anderson, H. R., Niciu, E. M., Wichmann, H. E., Kriz, B., Kosnik, M., Skorkovsky, J., Vonk, J. M., and Dortbudak, Z.: Acute effects of ozone on mortality from the "Air pollution and health: A European approach" project, Am. J. Resp. Crit. Care, 170, 1080-1087, 2004.

Gupta, M. L., Cicerone, R. J., and Elliott, S.: Perturbation to global tropospheric oxidizing capacity due to latitudinal redistribution of surface sources of $\mathrm{NO}_{\mathrm{x}}, \mathrm{CH}_{4}$ and $\mathrm{CO}$, Geophys. Res. Lett., 25, 3931-3934, 1998.

HEI International Scientific Oversight Committee: Health Effects of Outdoor Air Pollution in Developing Countries of Asia: A Literature Review, Health Effects Institute, Boston, USA, 124 pp., 2004.

Horowitz, L. W., Walters, S., Mauzerall, D. L., Emmons, L. K., Rasch, P. J., Granier, C., Tie, X. X., Lamarque, J. F., Schultz, M. G., Tyndall, G. S., Orlando, J. J., and Brasseur, G. P.: A global simulation of tropospheric ozone and related tracers: Description and evaluation of MOZART, version 2, J. Geophys. Res., 108, 4784, doi:10.1029/2002JD002853, 2003. 
Ito, K., De Leon, S. F., and Lippman, M.: Associations between ozone and daily mortality, Epidemiology, 16, 446-457, 2005.

Kim, S. Y., Lee, J. T., Hong, Y. C., Ahn, K. J., and Kim, H.: Determining the threshold effect of ozone on daily mortality: an analysis of ozone and mortality in Seoul, Korea, 1995-1999, Environ. Res., 94, 113-119, 2004.

Lelieveld, J. and Dentener, F. J.: What controls tropospheric ozone?, J. Geophys. Res., 105, 3531-3551, 2000.

Levy, J. I., Carrothers, T. J., Tuomisto, J. T., Hammitt, J. K., and Evans, J. S.: Assessing the public health benefits of reduced ozone concentrations, Environ. Health Persp., 109, 1215-1226, 2001.

Levy, J. I., Chemerynski, S. M., and Sarnat, J. A.: Ozone exposure and mortality: an empiric Bayes metaregression analysis, Epidemiology, 16, 458-468, 2005.

Naik, V., Mauzerall, D., Horowitz, L., Schwarzkopf, M. D., Ramaswamy, V., and Oppenheimer, M.: Net radiative forcing due to changes in regional emissions of tropospheric ozone precursors, J. Geophys. Res., 110, D24306, doi:10.1029/2005JD005908, 2005.

National Research Council: Estimating Mortality Risk Reduction and Economic Benefits from Controlling Ozone Air Pollution, National Academy Press, Washington, DC, USA, 226 pp., 2008.

Oak Ridge National Laboratory: Land Scan 2003, http://www.ornl. gov/sci/landscan., 2005.

O’Neill, M. S., Loomis, D., and Borja-Aburto, V. H.: Ozone, area social conditions, and mortality in Mexico City, Environ. Res., 94, 234-242, 2004.

Pope, C. A., Burnett, R. T., Thun, M. J., Calle, E. E., Krewski, D., Ito, K., and Thurston, G. D.: Lung cancer, cardiopulmonary mortality, and long-term exposure to fine particulate air pollution, JAMA-J. Am. Med. Assoc., 287, 1132-1141, 2002.

Prather, M., Ehhalt, D., Dentener, F., Derwent, R., Dlugokencky, E., Holland, E., Isaksen, I., Katima, J., Kirchhoff, V., Matson, P., Midgley, P., and Wang, M.: Atmospheric Chemistry and Greenhouse Gases, in: Climate Change 2001: The Scientific Basis, edited by: Houghton, J. T., Ding, Y., Griggs, D. J., Noguer, M., van der Linden, P. J., Dai, X., Maskell, K., and Johnson, C. A., Cambridge University Press, Cambridge, UK, 239-287, 2001.

Thurston, G. D. and Ito, K.: Epidemiological studies of acute ozone exposures and mortality, J. Expo. Anal. Env. Epid., 11, 286-294, 2001.
Vingarzan, R.: A review of surface ozone background levels and trends, Atmos. Environ., 38, 3431-3442, 2004.

Wang, Y. H. and Jacob, D. J.: Anthropogenic forcing on tropospheric ozone and $\mathrm{OH}$ since preindustrial times, J. Geophys. Res., 103, 31123-31135, 1998.

West, J. J. and Fiore, A. M.: Management of tropospheric ozone by reducing methane emissions, Environ. Sci. Technol., 39, 46854691, 2005.

West, J. J., Fiore, A. M., Horowitz, L. W., and Mauzerall, D. L.: Global health benefits of mitigating ozone pollution with methane emission controls, P. Natl. Acad. Sci. USA, 103, 39883993, 2006.

West, J. J., Fiore, A. M., Naik, V., Horowitz, L. W., Schwarzkopf, M. D., and Mauzerall, D. L.: Ozone air quality and radiative forcing consequences of changes in ozone precursor emissions, Geophys. Res. Lett., 34, L06806, doi:10.1029/2006GL029173, 2007a.

West, J. J., Szopa, S., and Hauglustaine, D. A.: Human mortality effects of future concentrations of tropospheric ozone, Comptes Rendus Geoscience, 339, 775-783, 2007b.

West, J. J., Naik, V., Horowitz, L. W., and Fiore, A. M.: Effect of regional precursor emission controls on long-range ozone transport - Part 1: Short-term changes in ozone air quality, Atmos. Chem. Phys., 9, 6077-6093, 2009, http://www.atmos-chem-phys.net/9/6077/2009/.

Wild, O. and Prather, M. J.: Excitation of the primary tropospheric chemical mode in a global three-dimensional model, J. Geophys. Res., 105, 24647-24660, 2000.

Wild, O., Prather, M. J., and Akimoto, H.: Indirect long-term global radiative cooling from $\mathrm{NO}_{\mathrm{x}}$ emissions, Geophys. Res. Lett., 28, 1719-1722, 2001.

World Health Organization: The World Health Report 2004: Changing History, World Health Organization, Geneva, 169 pp., 2004.

Wu, S. L., Duncan, B. N., Jacob, D. J., Fiore, A. M., and Wild, O.: Chemical nonlinearities in relating intercontinental ozone pollution to anthropogenic emissions, Geophys. Res. Lett., 36, L05806, doi:10.1029/2008GL036607, 2009. 